\title{
Role of Dietary Protein Adaptation at Weaning in the Development of the Rat Gastrointestinal Tract
}

\author{
JEAN PAUL BUTS AND MUTIJIMA NYAKABASA \\ Laboratory of Pediatric Gastroenterology and Nutrition, Unit of Gastroenterology, University of Louvain, \\ Brussels, Belgium
}

\begin{abstract}
To evaluate the role of the quantitative adaptation in dietary protein at weaning in the growth and maturation of the rat gastrointestinal tract, we studied parameters of tissue mass, DNA synthesis, and enzyme activities in suckling pups weaned by day 17 to a semipurified synthetic, isocaloric diet that contained either 8 or $27 \%$ casein (controls). Rats of both groups were studied on days 21,28 , and 35 postpartum. On day 21 , protein restriction had little effect on mean body weight, wet stomach and liver weight, gut length and colonic, jejunal or ileal mucosal weights per centimeter, whereas on day 35 , all these tissue mass parameters were significantly ( $p$ $<0.01$ versus controls) depressed in the $8 \%$ protein group. DNA and protein content expressed per intestinal segment or per total organ and the protein/DNA ratio paralleled the changes in tissue mass, except that total DNA of the small intestine was decreased by $33 \%(p<0.01$ versus controls) in 21-day-old rats with protein restriction. In the same age group, DNA synthesis rate, measured by the incorporation rate of $\left.{ }^{3} \mathrm{H}\right]$-thymidine per milligram tissue DNA, was markedly depressed in the small intestine (4fold decrease; $p<0.001$ versus controls) and in the liver ( 2 -fold decrease; $p<0.05$ versus controls) while in the colon the effect of protein restriction occurred later (day 35). Plasma corticosterone concentrations were equivalent in $8 \%$ and $27 \%$ protein groups on days 21 and 28 but on day 35 , the mean value in the $8 \%$ protein group fell to a level of about one-third of the controls $(p<0.01)$. Calculated for the total intestine, sucrase, maltase, and diamine oxidase activities remained unchanged in both groups throughout the experimental period indicating that the increases in specific enzyme activities in $8 \%$ protein rats were due to decreased tissue protein content. In $8 \%$ protein rats, both the specific and total activity of lactase, measured on days 28 and 35, was increased by at least 3-fold $(p<0.01)$ over the control values, whereas aminopeptidase activity was significantly decreased $(p<0.05$ versus controls). Our data demonstrate that the adaptation in dietary protein at weaning modulates the ontogenic changes in tissue DNA synthesis and plays a role in completing the growth of the rat gastrointestinal tract. However, this dietary adaptation is not critical for the maturation of functions linked to intestinal absorption. (Pediatr Res 19: 857-862, 1985)
\end{abstract}

Received November 1, 1984; accepted April 2, 1985.

Requests for reprints should be addressed to Jean-Paul Buts, M.D., Departement of Pediatrics, University of Louvain, Clinique Saint-Luc, 10 avenue Hippocrate, B-1200 Brussels, Belgium.

Supported by the FRSM (Fonds de recherche Scientifique Médicale) Belgium (Grant 3-4551/84) and by Nestlé International Nutrition Research Grant Program.
Abbreviation

DAO, diamine oxidase

Although the development of the rat gastrointestinal tract can be accounted for by an increase in the number of cells (1), cell proliferation rate in different regions of the gut does not follow an identical ontogenic pattern. During the $3 \mathrm{rd}$ postnatal wk, mucosal DNA synthesis and cell proliferation rate increase 4- to 5 -fold in the small intestine leading to mucosal hyperplasia (24), whereas in the stomach (5) and in the colon (6) there is no increase or even a decrease in these cell kinetic parameters. Similarly, thymidine kinase activity rises markedly in the jejunum of the weanling rat between days 16 and 24 (3), whereas the enzyme activity decreases during the same time period in the stomach (5) and colon (7).

The mechanism(s) that controls the ontogenic changes in cell division and proliferation of the developing gut are far from well understood. Initiation of the postnatal ontogenic events in the rat gastrointestinal tract is probably determined by the genetic program (8), while the terminal phase of intestinal development seems to be influenced by environmental factors such as nutrients (9), hormones (9), and mediators $(4,9)$. Regarding dietary factors, the weaning period is characterized by a shift from a liquid fatrich, low-iron diet supplied by the mother $(10)$ to a solid diet rich in carbohydrates and iron (rat food). It has been demonstrated that the proportion of carbohydrate relative to fat (11) and the iron content (12) of the weanling diet are critical for the maturation of intestinal microvillous enzymes but not for the ontogenic changes in DNA synthesis $(3,12)$.

The present study is concerned with another aspect of the dietary adaptation at weaning: the amount of protein consumed. Rat milk contains about $9 \mathrm{~g}$ protein per $100 \mathrm{ml}(10)$, whereas the protein content of rat food pellets may be as high as $27 \mathrm{~g} /$ $100 \mathrm{~g}$ solids. During the first $2 \mathrm{wk}$ of life, the suckling process depends on several variables (9) but under conditions of normal litter size, the quantity of milk ingested has been estimated to average $3 \mathrm{~g} /$ rat per day (10). On the 16 th postnatal day, the pups begin to nibble solid food and show a gradually decreasing consumption of milk through the next week until they are ingesting $100 \%$ solids by the 23 rd day (9). Daily measurements of food intake have confirmed that during the $3 \mathrm{rd}$ and 4 th $\mathrm{wk}$ the consumption of rat food increases from 2 to $6 \mathrm{~g} /$ rat per day (12). Thus, compared to the suckling period, the weanling pericid is characterized by a rapid adaptation in the quantity and quality of proteins ingested per day. As far as we can determine, the importance of the protein content of the weanling diet for the maturation of the rat digestive tract has not yet been investigated. 
The aim of the present study is 1) to examine the possible influence of the quantitative adaptation in dietary protein at weaning on the terminal maturation of the rat small intestine and 2) to evaluate the effects of acute protein restriction during this critical period on the growth pattern of the stomach, liver, small intestine, and colon.

\section{MATERIALS AND METHODS}

Animals. Pregnant rats of the Wistar strain were obtained commercially on the 12 th day of gestation and were housed individually in polystyrene cages with a 12-h light-dark circle. The day of birth was defined as day 0 . Each mother nursed 10 to 14 pups (normal litter size) and was housed separately with her group of pups. The pups had free access to the nipples. Dams were fed laboratory food (N 103. UAR. Villemoisson-sur-Orge, France) and water ad libitum until day 15 when experiments began.

Procedwes. On day 15 the pups were pooled and separated into two groups of 21 rats each. Group I was fed ad libitum a semipurified synthetic diet containing $27 \%$ casein (controls). Rats of group II were weaned onto a low protein, isocaloric diet containing $8 \%$ casein. The composition of the diets is detailed in Table I. The animals were separated from the dams on day 17. Seven rats of each group were studied on days 21,28 , and 35 postpartum.

Animals were housed in mctabolic cages and food intake was measured daily in both groups.

Preparation of tissues. On the day of study, the animals were killed by decapitation. The entire small intestine (from the pyloric end to the ileocecal valve) was removed and trimmed of fat and mesentery. The intestinal length was measured under fixed tension as described (2) and divided into two equal segments. The proximal segment was defined as the duodenojejunum and the distal segment as the ilcum. Each segment was opened longitudinally, rinsed in ice-cold saline, blotted on filter paper, and weighed. The mucosa was scraped and weighed separately. Except for mucosal separation, the same procedure was applied to the colon. The stomach was also excised, opened lengthwise, rinsed thoroughly to remove luminal content, blotted on filter paper, and weighed. The liver was trimmed of fat and weighed. All tissues were wrapped in parafilm and frozen immediately. Tissues and mucosa from each rat were separately sonicated (Branson Sonifier B 12) and were prepared for the determination of protein and DNA. Enzyme activites were measured in duodenojejunal mucosa homogenized and diluted (1/ $500-1 / 15000$ ) in appropriate buffers (Tris-Maleate, $\mathrm{pH}=6.0$, for disaccharidases and 2-amino-2-methylpropandiol, $\mathrm{pH}=8.0$, for aminopeptidase).

Biochemical determinations. Plasma corticosterone was measured by a specific protein-binding assay on specimens of blood collected from 42 rats (control and experimental groups) killed at the ages described above. The procedures for blood collection and for corticosterone assay have been described in detail previously (6).

For the determination of DNA synthesis rates, $2 \mu \mathrm{Ci} / \mathrm{g}$ body weight of $\left[{ }^{3} \mathrm{H}\right]$-thymidine (specific activity $23 \mathrm{Ci} / \mathrm{mmol}$ Amersham, England) was injected intraperitoneally to each animal. The injections were all given at the same hour in the morning to

Table 1. Composition of the synthetic diets $(g / k g d r y w t)$

\begin{tabular}{lrc} 
& \multicolumn{2}{c}{ Diet } \\
\cline { 2 - 3 } & $8 \%$ protein & $27 \%$ protein \\
\hline Casein & 80 & 270 \\
Starch & 780 & 590 \\
Vegetable oil & 100 & 100 \\
Mineral mixture & 40 & 40 \\
Calorics & 4426 & 4426 \\
\hline
\end{tabular}

circumvent circadian periodicity in DNA synthesis (14). The animals were sacrificed $24 \mathrm{~h}$ after the injection allowing sufficient time for uniform distribution of the label. Tissue samples (100 $\mathrm{mg}$ ) of the liver, colon, and duodenojejunal and ileal mucosa were homogenized in $8 \mathrm{ml}$ of $0.25 \mathrm{~N}$ cold perchloric acid as described by Johnson and Guthrie (13) and assayed for DNA by the diphenylamine method of Burton (15) as modified by Giles and Myers (16). Polymerized calf thymus DNA (Sigma Chemicals) was used as standard. The amount of $\left[{ }^{3} \mathrm{H}\right]$-thymidine incorporated into DNA was determined by counting $0.5 \mathrm{ml}$ of the DNA extract in a Beckman scintillation system. DNA extracts were counted in duplicate. Protein content in mucosa and in tissues was measured by the Lowry method (17).

Lactase, maltase, and sucrase activities were assayed by the method of Messer and Dahlquist (18). Disaccharidase activities were expressed as $\mu$ moles of substrate hydrolyzed per minute per gram protein. Aminopeptidase was assayed according to Maroux et al. (19) using L-alanine-p-nitroanilide as substrate. One unit equals $1 \mu \mathrm{mol}$ of $p$-nitroaniline formed per minute per gram protein. DAO, a cytosolic marker of the mature villous enterocyte (20), was assayed according to Okuyama and Kobayashi (21). Labeled putrescine was used as substrate. $\left[{ }^{3} \mathrm{H}\right]$-putrescine (specific radioactivity of $40.5 \mathrm{Ci} / \mathrm{mmol}$, New England Nuclear, Boston, MA) was mixed with unlabeled putrescine in order to reach a specific radioactivity of $1 \mathrm{Ci} \mathrm{mmol}^{-1}$ (160 pmol yielding approximately 170,000 counts $/ \mathrm{min})$. The reaction product $(\triangle 1$ pyrroline) was extracted in toluene. DAO activity was expressed as nanomoles putrescine deaminated per hour per gram protein. Activities were shown to be proportional to time and quantity of enzyme.

Calculations and statistics. All results were expressed as mean \pm SE. DNA was calculated in milligrams per gram tissue and DNA synthesis rates in (counts/min) per milligram DNA. Since specific activity is a function of both enzyme activity and tissue protein content, a change in this value could be caused not only by a change in the numerator, but also by a change in the denominator. Therefore, we have also expressed the data as total activity per segment removing the possibility of an artifact when data are related solely to protein or DNA. Differences between means were tested for statistical significance using a 1-way analysis of variance and the unpaired Student's $t$ test, when the F value allowed statistical comparison. Where not appropriate, the groups were compared by the Mann-Whitney U test.

\section{RESULTS}

Daily food intake was similar in protein-deprived rats (increasing from 3.5 to $5.2 \mathrm{~g} / \mathrm{rat} / \mathrm{day}$ ) and in controls (increasing from 3.7 to $5.6 \mathrm{~g} / \mathrm{rat} /$ day).

Table 2 summarizes the developmental changes in body weight and the weight of different organs of the gastrointestinal tract. After 5 days of feeding a solid diet (day 21), there was little change in body weight and wet tissue weight of the stomach, liver, small intestine, and colon between rats weaned onto the low protein diet ( $8 \%$ casein) and the controls ( $27 \%$ casein). By days 28 and 35 , protein restriction led to an inhibition of body weight gain and to a significant $(p<0.01)$ decrease in the weight of the stomach $(-44 \%)$ and of the liver $(-42 \%)$ versus controls. In protein-deprived rats, the growth of the small intestine in length was altered and both duodenojejunal (day 28: $-33 \%$; day 35: $-34 \%$ ) and ileal (day $28:-35 \%$ day $35:-39 \%$ ) mass calculated per unit of length was significantly $(p<0.01)$ decreased compared to the respective control groups. Compared to the small intestine, the decrease in colonic weight per unit length was slight on day 28 ( $-13 \%$ versus controls) but became more pronounced on day $35(-24 \%$ versus controls; $p<0.01)$. Protein content in the liver, duodenojejunum, ileum, stomach, and colon of rats undergoing protein restriction generally reflected the changes in tissue mass. Tissue protein content expressed per mucosal weight or per organ was unchanged on day 21 but was significantly $(p<0.01)$ decreased on days 28 and 35 (Table 3 ). 
Table 2. Effect of protein restriction at weaning on the developmental changes in body wt, intestinal length, and wt of different organs of the gastrointestinal tract

\begin{tabular}{|c|c|c|c|}
\hline \multirow[b]{2}{*}{ Parameter } & \multicolumn{3}{|c|}{ Age } \\
\hline & Day 21 & Day 28 & Day 35 \\
\hline \multicolumn{4}{|l|}{ Body wt (g) } \\
\hline$C^{*}$ & $26.1 \pm 1.2 \dagger$ & $28.4 \pm 0.1$ & $39.5 \pm 2.4$ \\
\hline LPD & $26.0 \pm 1.9$ & $21.0 \pm 0.1 \div$ & $20.7 \pm 1.0 \div$ \\
\hline \multicolumn{4}{|l|}{ Liver wt (mg) } \\
\hline $\mathrm{C}$ & $961 \pm 53$ & $1836 \pm 105$ & $3073 \pm 175$ \\
\hline LPD & $908 \pm 33$ & $1079 \pm 152 \ddagger$ & $\begin{array}{l}1362 \pm \\
107 t\end{array}$ \\
\hline \multicolumn{4}{|l|}{ Stomach wt (mg) } \\
\hline C & $252 \pm 18$ & $412 \pm 19$ & $471 \pm 35$ \\
\hline LPD & $220 \pm 10$ & $233 \pm 16 \ddagger$ & $279 \pm 13 \ddagger$ \\
\hline \multicolumn{4}{|c|}{ Intestinal length $(\mathrm{cm})$} \\
\hline $\mathrm{C}$ & $45.7 \pm 2.1$ & $68.7 \pm 1.1$ & $75.2 \pm 1.5$ \\
\hline LPD & $43.4 \pm 0.8$ & $55.6 \pm 2.1 \%$ & $63.3 \pm 1.7+$ \\
\hline \multicolumn{4}{|c|}{$\begin{array}{l}\text { Duodenojejunal wt } \\
\qquad(\mathrm{mg} / \mathrm{cm})\end{array}$} \\
\hline $\mathrm{C}$ & $36.9 \pm 3.6$ & $41.2 \pm 1.9$ & $46.6 \pm 1.8$ \\
\hline LPD & $33.6 \pm 1.7$ & $28.8 \pm 1.6 \ddagger$ & $31.1 \pm 0.1 \div$ \\
\hline \multicolumn{4}{|l|}{ Ileal wt $(\mathrm{mg} / \mathrm{cm})$} \\
\hline C & $23.0 \pm 2.2$ & $30.5 \pm 1.6$ & $32.1 \pm 1.4$ \\
\hline LPD & $25.1 \pm 2.5$ & $20.1 \pm 1.2 \ddagger$ & $19.6 \pm 1.8 \neq$ \\
\hline \multicolumn{4}{|c|}{ Colonic wt $(\mathrm{mg} / \mathrm{cm})$} \\
\hline $\mathrm{C}$ & $43.8 \pm 2.7$ & $52.7 \pm 0.9$ & $53.9 \pm 2.2$ \\
\hline LPD & $43.3 \pm 1.7$ & $46.1 \pm 1.8 \%$ & $33.6 \pm 1.3+$ \\
\hline
\end{tabular}

${ }^{*} \mathrm{C}$, controls fed $27 \%$ casein diet: LPD, rats fed low protein diet containing $8 \%$ casein.

$\dagger$ Values represent mean \pm SE of seven individual observations for each group

$\ddagger$ Significantly lower than controls at a level of $p<0.01$.

Table 3. Specific activities of small intestinal mucosal enzymes measured at different ages in rats weaned onto a diet containing either 8 or $27 \%$ casein

\begin{tabular}{|c|c|c|c|}
\hline \multirow[b]{2}{*}{ Enzyme } & \multicolumn{3}{|c|}{ Age } \\
\hline & Day 21 & Day 28 & Day 35 \\
\hline \multicolumn{4}{|c|}{ Lactase (U/g protein)* } \\
\hline $\mathrm{C}^{\dagger}$ & $18.3 \pm 5.0 \neq$ & $0.3 \pm 0.3$ & $0.4 \pm 0.3$ \\
\hline LPD & $18.7 \pm 4.0$ & $9.9 \pm 2.9 \S$ & $3.6 \pm 1.2 \S$ \\
\hline \multicolumn{4}{|c|}{ Sucrase (U/g protein)* } \\
\hline $\mathrm{C}$ & $36.4 \pm 10.5$ & $27.9 \pm 6.2$ & $26.7 \pm 3.0$ \\
\hline LPD & $50.9 \pm 7.7$ & $79.0 \pm 10.8 \S$ & $74.3 \pm 11.2 \S$ \\
\hline \multicolumn{4}{|c|}{ Maltase (U/g protein) $)^{*}$} \\
\hline C & $242 \pm 47$ & $152 \pm 17$ & $188 \pm 10$ \\
\hline LPD & $327 \pm 29$ & $401 \pm 42 \S$ & $305 \pm 30 \S$ \\
\hline \multicolumn{4}{|c|}{$\begin{array}{l}\text { Aminopeptidase (U/g } \\
\text { protein)* }\end{array}$} \\
\hline $\mathrm{C}$ & $83.6 \pm 6.8$ & & $73.2 \pm 5.5$ \\
\hline LPD & $63.1 \pm 4.6 \|$ & & $28.5 \pm 5.2 \S$ \\
\hline \multicolumn{4}{|c|}{$\begin{array}{l}\text { Diamine oxidase (U/g } \\
\text { protein) }\end{array}$} \\
\hline $\mathrm{C}$ & $39.2 \pm 16.3$ & & $257 \pm 89$ \\
\hline LPD & $39.3 \pm 13.8$ & & $273 \pm 33$ \\
\hline \multicolumn{4}{|c|}{ Protein (mg/g mucosa) } \\
\hline $\mathrm{C}$ & $110 \pm 3.6$ & $103 \pm 1.1$ & $113 \pm 1.4$ \\
\hline LPD & $97 \pm 5.3$ & $77 \pm 0.7 \S$ & $79 \pm 1.6 \S$ \\
\hline
\end{tabular}

* Unit $=\mu \mathrm{mol}$ of substrate hydrolyzed per minute.

$\dagger \mathrm{C}$, controls fed a $27 \%$ casein diet: $L P D$, rats fed a $8 \%$ casein diet.

$\$$ Each value represents mean \pm SE of seven individual observations.

$\S$ Significantly different from controls at a level of $p<0.01$.

$\|$ Significantly different from controls at a level of $p<0.05$.

If Unit $=$ nmol of putrescine deaminated per hour.
The changes in total DNA content of the small intestine, stomach, colon, and liver are depicted in Figure 1. Protein restriction caused a rapid and significant $(p<0.01)$ decrease $(-33 \%)$ in intestinal DNA content (mucosa and whole tissue) which was already apparent by day 21 , whereas significant changes in liver and colonic DNA content were only observed in the 35-day-old group. Changes in total gastric DNA were comparable to those observed in the small intestine, except that the difference in gastric DNA content between the experimental and control group was not statistically significant on day 21 . Reflecting early changes in mucosal DNA with minimal changes in corresponding tissue protein, the protein/DNA ratio of the intestinal mucosa was initially (day 21$)$ greater $(p<0.05)$ in protein-deprived rats than in controls (Fig. 2). However, on days 28 and 35 , the ratio fell to a level of about one-half of the controls in the small intestine and in the liver. In the colon, the ratio was also significantly ( $p<0.01$ versus controls) diminished, while it remained unchanged in the stomach. The impact of protein restriction at weaning on the ontogenic changes in DNA synthesis

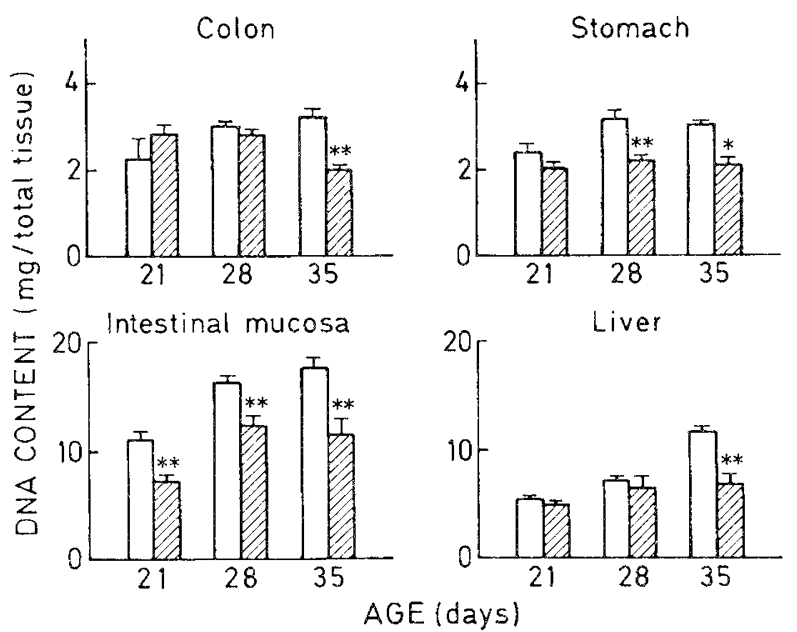

Fig. 1. Effect of protein restriction at weaning on changes in DNA content of the colon, stomach, intestinal mucosa, and liver. Rats were weaned onto a diet containing either $8 \%$ casein (shaded bar) or $27 \%$ casein (controls. open bar) and were studied on days 21,28 , and 35 of age. Each value represents the mean $\pm \mathrm{SE}$ of seven to eight individual observations. ${ }^{*} p<0.05,{ }^{* *} p<0.01$.

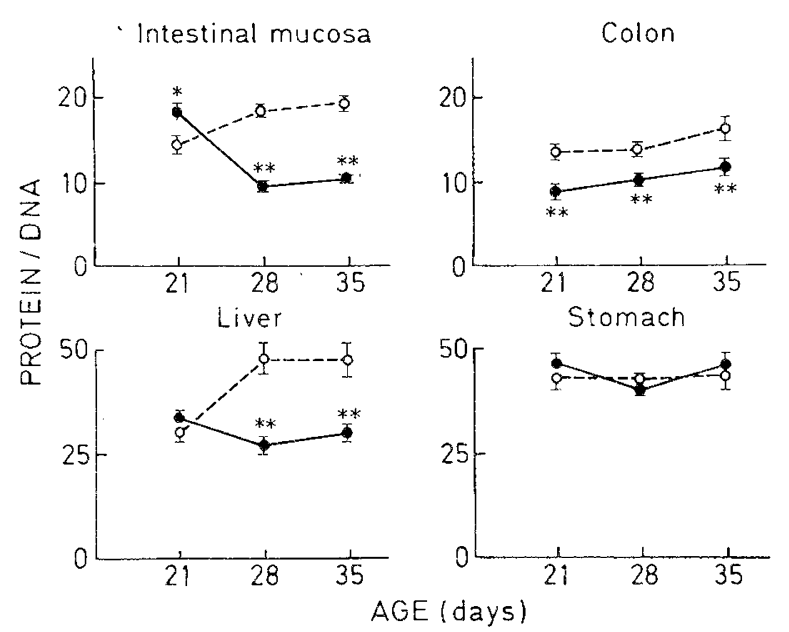

Fig. 2. Comparative changes in the protein/DNA ratio of the intestinal mucosa, colon, liver, and stomach of rats weaned onto a $8 \%$ casein diet (closed circles) or onto a $27 \%$ casein diet (controls, open circles). Experimental and control groups were studied on days 2128 , and 35 of age. Each value represents the mean $\pm \mathrm{SE}$ of seven to eight individual observations. ${ }^{*} p<0.05,{ }^{* *} p<0.01$. 


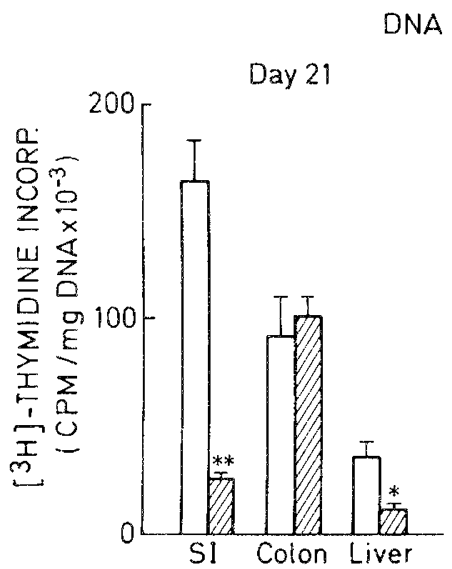

DNA SYNTHESIS

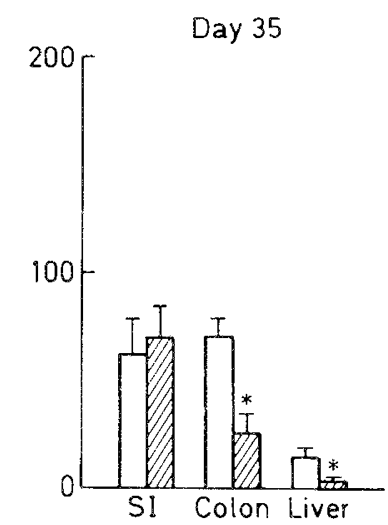

Fig. 3. Effect of protein restriction at weaning on changes in DNA synthesis of the small intestine, colon, and liver. DNA synthesis rate was measured by the in vivo incorporation of $\left[{ }^{3} \mathrm{H}\right]$-thymidine (pulse administration of $2 \mu \mathrm{Ci} / \mathrm{g}$ body weight) expressed per milligram of tissue DNA. Experimental ( $8 \%$ casein, shaded bar) and control $(27 \%$ casein, open bar) rats were studied on days 21 and 35 . Each value represents mean \pm $\mathrm{SE}$ of seven to eight individual observations. ${ }^{*} p<0.05,{ }^{* *} p<0.001$.

Table 4. Enzyme activities for total small intestine in rats weaned onto a diet containing either 8 or $27 \%$ casein

\begin{tabular}{|c|c|c|c|}
\hline \multirow{2}{*}{$\begin{array}{l}\text { Total enzyme activity } \\
\text { (per total intestinal length) }\end{array}$} & \multicolumn{3}{|c|}{ Age } \\
\hline & Day 21 & Day 28 & Day 35 \\
\hline \multicolumn{4}{|l|}{ Lactase* } \\
\hline $\mathrm{C}^{\dagger}$ & $2.1 \pm 0.8 \div$ & $0.07 \pm 0.06$ & $0.18 \pm 0.12$ \\
\hline LPD & $2.5 \pm 0.6$ & $1.27 \pm 0.4 \S$ & $0.55 \pm 0.228$ \\
\hline \multicolumn{4}{|l|}{ Sucrase* } \\
\hline C & $6.0 \pm 1.8$ & $7.6 \pm 1.9$ & $5.7 \pm 1.0$ \\
\hline LPD & $8.0 \pm 1.2$ & $9.5 \pm 1.7$ & $6.4 \pm 2.1$ \\
\hline \multicolumn{4}{|l|}{ Maltase* } \\
\hline C & $39.3 \pm 8.9$ & $40.6 \pm 4.5$ & $30.2 \pm 2.7$ \\
\hline LPD & $43.5 \pm 5.0$ & $48.0 \pm 7.6$ & $41.5 \pm 5.6$ \\
\hline \multicolumn{4}{|l|}{$\mathrm{DAO}(5)$} \\
\hline $\mathrm{C}$ & $6.8 \pm 3.0$ & & $91.8 \pm 36.2$ \\
\hline LPD & $4.8 \pm 1.4$ & & $67.7 \pm 4.2$ \\
\hline
\end{tabular}

* Unit $=\mu \mathrm{mol}$ of substrate hydrolyzed per minute.

$+C$, controls fed $27 \%$ casein diet; LPD, rats fed $8 \%$ casein diet.

$\$$ Each value represents mean \pm SE of seven individual observations.

$\S$ Significantly different from controls at a level of $p<0.01$.

$\|$ Unit $=$ nmol of putrescine deaminated per hour.

of the different gastrointestinal tissues are shown in Figure 3. In 21 -day-old rats, weaned onto the low protein diet, DNA synthesis rate was markedly depressed, more than 4 -fold ( $p<0.001$ versus controls) in the small intestine and more than 2-fold $(p<0.05$ versus controls) in the liver. The incorporation rate of labeled thymidine per milligram of colonic DNA was initially (day 21) equivalent between protein-deprived rats and controls but at the age of 35 days, colonic DNA synthesis decreased to a level $36 \%$ of controls. Interestingly, in the same age group, intestinal DNA synthesis rate had returned to the control level which is normally lower during the 4 th and 5 th postnatal wk than during the 3rd wk (3).

The effects of protein restriction on the maturation of intestinal mucosal enzymes are detailed in Table 3 (specific enzyme activity) and in Table 4 (total enzyme activity). Both the specific (per unit protein) and total (per total intestine) lactase activity was increased in rats weaned onto the $8 \%$ protein diet. Compared to the controls, the increases in lactase activity were found to be significant on days $28(p<0.01)$ and $35(p<0.01)$. Similar data
Table 5. Effect of protein deprivation at weaning on changes in plasma total corticosterone concentration

\begin{tabular}{clc} 
& \multicolumn{2}{c}{ Corticosterone level $(\mu \mathrm{g} / 100 \mathrm{ml})$} \\
\cline { 2 - 3 } Age & $8 \%$ casein & $27 \%$ casein (controls) \\
\hline Day 21 & $25.2 \pm 3.5^{*}$ & $20.8 \pm 1.8$ \\
Day 28 & $30.8 \pm 3.5$ & $26.9 \pm 2.5$ \\
Day 35 & $12.6 \pm 2.1 \dagger$ & $37.2 \pm 3.7$ \\
\hline
\end{tabular}

* Values represent mean \pm SEM of seven individual determinations.

$\dagger$ Significantly lower than controls $(p<0.01)$.

showing lactase stimulation have been reported in animals undergoing starvation (22) or chronic protein malnutrition (23, $24)$. In the same age groups, the specific activity of sucrase and of maltase was also enhanced, when compared to $27 \%$ protein controls. This was obviously due to loss of tissue protein (denominator) since the total activity of these latter two enzymes per total intestine was similar in control and experimental groups. DAO activity (specific and total) remained unchanged while as expected (19), aminopeptidase activity fell significantiy on days $21(-25 \% ; p<0.05$ versus controls) and $35(-61 \% ; p<0.01)$ in response to protein restriction.

To assess whether the very early changes in intestinal DNA synthesis observed in protein-deprived rats could have been mediated through glucocorticoids, we measured the plasma concentration of total corticosterone (free and bound) on days 21 , 28 , and 35 . On days 21 and 28 , the circulating levels were noted to be slightly but not significantly higher in the $8 \%$ protein group but on day 35 , the values fell to a level of about one-third of that of the controls (Table 5).

\section{DISCUSSION}

Between days 17 and 21 of age, the postnatal development of the rat small intestine is characterized by marked increases in villus height, crypt depth, cell migration rate, mucosal mass, and DNA and RNA content $(2,4)$. During the same critical period, several mucosal enzymes also rapidly adapt (9). All these ontogenic changes are directed toward the adult pattern and are correlated with maturative changes in other organs of the gastrointestinal tract, including the mouth, stomach, colon, liver, and pancreas (9). At the end of the 4th postnatal wk, the maturative process appears to be complete since the gastrointestinal tract has reached adult absorptive capacities.

Because these ontogenic changes coincide with the time of weaning, it has been implied that this may be a result of a change in diet. Previous experiments $(3,8)$ in weaning rats have suggested that the initiation of changes in intestinal cell proliferation, DNA synthesis, and mucosal enzymes are not diet dependent but could be triggered by the interaction of the genetic program and hormonal mediators. In the present study, we have examined the importance of the dietary adaptation in protein (transition from rat milk to food pellets) in the development of the gastrointestinal tract and especially for the terminal maturation of the rat small intestine. Our study demonstrates that the protein content of the weaning diet modulates the ontogenic changes in DNA synthesis and is a factor in the completion of the growth of the gastrointestinal tract. When suckling pups were weaned onto a diet that contained a concentration $(8 \mathrm{~g} / 100 \mathrm{~g})$ of protein equal to that of rat milk $(9 \mathrm{~g} / 100 \mathrm{ml})$, DNA synthesis rate measured on day 21 was reduced 4 -fold in the small intestine and 2-fold in the liver as compared to control littermates weaned onto a $27 \%$ protein diet. The values in the small intestine of 21 day-old rats undergoing protein restriction were comparable to those obtained in the same organ of 14-day-old suckling rats (3). The impact of protein restriction at weaning on tissue DNA synthesis is further attested by the significant decrease in total 
DNA calculated per organ and in the protein/DNA ratio, suggesting both a reduction in the number of cells and in mean cell size $(1,26)$. The response to protein restriction was rapid (within 5 days) in the small intestine and in the liver but it appeared delayed in the colon. These differences could be related to differences in the normal rate of cell turnover which varies from one tissue to another and to the fact that different organs of the rat immature gastrointestinal tract do not folow an identical developmental pattern. Indeed, at weaning, cell proliferation, DNA synthesis rate and thymidine kinase activity increase 4- to 5 -fold in the rat small intestine $(3,7)$, while in the stomach and in the colon, it has been shown that the same parameters tend to decrease in variable proportions $(5-7)$.

Chronic protein malnutrition $(23,27)$ and starvation (24) have a particularly severe impact on the young animal and its small intestine. Guiraldes and Hamilton (23) found that young pups with chronic protein-calorie malnutrition, when initiated early in the neonatal period, exhibited a delay in the normal maturation of the small intestinal epithelium. The protein and DNA content of the small intestine, enterocyte migration rate along the villi and the total activity of a variety of mucosal enzymes significantly decreased in the pups as maternal dietary protein was diminished. Prolonged nursing which extends the consumption of the lactose diet (rat milk) also causes retarded intestinal growth $(8,28)$. However, as previously pointed out $(29)$, retarded growth in this type of experiment is more likely related to a restricted supply of nutrients rather than to a change in nutrient composition in the diet. Other possible interfering factors include changes in milk composition, feeding behavior of the pups, decreased milk intake per body weight, and hormonal variations (8). In the present study, the synthetic diets used were isocaloric and dietary intake measured daily was equivalent in experimental and control groups.

An important aspect to be discussed in relation to our findings is the effect of the restriction in dietary protein on intestinal mucosal enzymes. The specific activity of sucrase and maltase was preserved at day 21 but increased above control levels at days 28 and 35 . These changes were obviously the result of protein loss since the total activity of these enzymes (calculated per total intestine) remained unchanged. Similarly, DAO activity (specific and total), which is a cytosolic marker of the mature villus enterocyte (20), was similar in 8 and $27 \%$ protein rats. These findings suggest that the dietary adaptation in protein at weaning has little influence on the maturation of functions linked to the villus cell.

A special reference has to be made about lactase activity (specific and total) which was at least three times higher in $8 \%$ protein rats than in controls. Enhanced lactase activity has been observed in adult rats subjected to fasting, semistarvation, or to protein deprivation $(22,30)$, in weanling rats deprived of protein (24) and in chronically malnourished suckling rats $(23,27)$. A recent study (31) has demonstrated that the stimulation of lactase activity during starvation is the result of de novo synthesis of new molecules and that this process is regulated at a translational level. The exact stimulus is not known but a key role for thyroxine in the regulation of the enzyme has been shown both in weanling rats (9) and in adult rats subjected to starvation (25). On the other hand, a possible influence of dietary lactose on the developmental pattern of mucosal lactase in rats has also been evoked because pups nursed for prolonged periods exhibit persistently higher levels of lactase than do weaned controls (28). In the present study, the stimulation of lactase activity occurred in the absence of a corresponding increase in dietary lactose which reaffirms the importance of nondietary factors in the regulation of the enzyme.

The mechanism(s) by which nutritional protein restriction inhibits intestinal mucosal growth is not clearly established. In addition to the effect of protein restriction on the synthesis of pyrimidine biosynthetic enzymes, one has to consider the possi- bility of indirect effects mediated through hormones. Glucocorticoids have been shown to be potential inhibitors of DNA synthesis in adult growing rat small intestine $(3,32)$ and colon (6). However, from the data reported in Table 5, there is no suggestive evidence for a corticosterone-mediated response. Since the values for corticosterone obtained in both groups are 20 to $40 \%$ higher than the basal values we reported previously in weaning rats $(6)$, the lower values in the $8 \%$ casein group on day 35 could reflect a reduced responsiveness to stress rather than any change in basal secretion. Further studies on trophic gut hormones, such as gastrin and epidermal growth factor, would be of particular interest to clarify the mechanism by which dietary proteins regulate intestinal growth.

Acknowledgments. The authors thank Nadine De Keyser and Sylvie Paquet for expert technical assistance and Penelope Brock for helpful comments on the manuscript.

\section{REFERENCES}

1. Enesco M, Leblond CP 1962 Increase in cell number as a factor in the growth of the organs and tissues of the young male rat. J Embryol Exp Morphol 10:530-562

2. Buts JP, De Meyer R 1981 Postnatal proximodistal development of the small bowel mucosal mass in growing rats. Biol Neonate 40:62-69

3. Buts JP, De Meyer R 1984 Intestinal development in the suckling rat: effects of weaning, diet composition and glucocorticoids on thymidine kinase activity and DNA synthesis. Pediatr Res 18:145-150

4. Klein RM, McKenzie JC 1983 The role of cell renewal in the ontogeny of the intestine. I. Cell proliferation patterns in adult, fetal and neonatal intestine. J Pediatr Gastroenterol Nutr 2:204-228

5. Majumdar APN, Johnson LR 1982 Gastric mucosal cell proliferation during development in rats and effects of pentagastrin. Am J Physiol 242:G135G139

6. Buts JP, De Meyer R, Kolanowsky J 1983 Ontogeny of cell proliferation and DNA synthesis in rat colon: role of glucocorticoids. Am J Physiol 244:G469G474

7. Herzfeld AM, Raper SM, Gore I 1980 The ontogeny of thymidine kinase in tissues of man and rat. Pediatr Res 14:1304-1310

8. Lee PC, Lebenthal E 1983 Early weanling and precocious development of small intestine in rats: genetic, dietary or hormonal control. Pediatr Res $17: 645-650$

9. Henning SJ 1981 Postnatal development: coordination of feeding, digestion and metabolism. Am J Physiol 241:G199-G214

10. Dymsza HA, Czajka DM, Miller SA 1964 Influence of artificial diet on weight gain and body composition of the neonatal rat. J Nutr 84:100-106

11. Henning SJ, Guerin DM 1981 Role of diet in the determination of jejunal sucrase activity in the weanling rat. Pediatr Res 15:1068-1072

12. Buts JP, Delacroix D, De Keyser N, Paquet S, Horsmans Y, Boelens M, Van Craynest MP, De Meyer R 1984 Role of dietary iron in maturation of rat small intestine at weaning. Am J Physiol 246:G725-G731

13. Johnson LR, Guthrie PD 1974 Mucosal DNA synthesis: a short term index of the trophic action of gastrin. Gastroenterology 67:453-459

14. Hageman RF, Sigdestad CP, Lesher S 1970 A method for quantitation of proliferative intestinal mucosal cells on a weight basis: some values for $\mathrm{C} 57$ BL/6. Cell Tissue Kinet 3:21-26

15. Burton K 1956 A study of the conditions and mechanism of the diphenylamine reaction for the colorimetric estimation of deoxyribonucleic acid. Biochem J 62:315-323

16. Giles KW, Meyers M 1965 An improved diphenylamine method for the estimation of DNA. Nature 206:93-94

17. Lowry OH, Rosebrough NJ, Farr AL, Randall RJJ 1951 Protein measurement with the folin reagent. J Biol Chem 193:265-275

18. Messer M, Dahlqvist A 1966 A one step ultramicromethod for the assay of intestinal dissaccharidases. Anal Biochem 14:376-392

19. Maroux S, Louvard D, Baratti J 1973 The aminopeptidase from the hog intestinal brush border. Biochim Biophys Acta 321:282-295

20. Luk D, Bayless TM, Baylin S 1980 Diamine oxydase (histaminase) circulating marker for rat intestinal mucosal maturation and integrity. J Clin Invest 66:66-70

21. Okuyama T, Kobayashi Y 1961 Determination of diamine oxydase activity by liquid scintillation counting. Arch Biochem Biophys 95:242-250

22. Yamada K, Goda T, Bustamante S, Koldovsky O 1983 Different effect of starvation on activity of sucrase and lactase in rat jejunoileum. Am J Physiol 224:G449-G455

23. Guiraldes E, Hamilton RJ 1981 Effect of chronic malnutrition on intestinal structure, epithelial renewal and enzymes in suckling rats. Pediatr Res 15:930-934

24. Prosper J, Murray RL, Kern F 1968 Protein starvation and the small intestine II Disaccharidases activities. Gastroenterology 55:223-228 
25. Raul F, Noriega R, Ngi-Emvo E, Doffoel M, Grenier JF 1983 Lactase activity is under hormonal control in the intestine of adult rat. Gut 24:648-652

26. Koldovsky O, Herbst $J J$, Burke $J$, Sunshine $P 1970$ RNA and DNA in intestinal mucosa during development of normal and cortisone-treated rats. Growth 34:359-367

27. Hatch TF, Lebenthal E, Branski D 1979 Effect of early postnatal acquired malnutrition on intestinal growth, disaccharidases and enterokinase. $J$ Nutr 109:1874-1879

28. Lebenthal E, Sunshine P. Kretchmer N 1973 Effect of prolonged nursing on the activity of intestinal lactase in rats. Gastroenterology 64:1136-1141

29. Lebenthal E. Sunshine P, Kretchmer N 1972 Effect of carbohydrate and corticosteroids on activity of $\alpha$-glucosidases in intestine of the infant rat J Clin Invest 51:1244-1250

30. Solimano G, Burges EA, Levin B 1967 Protein-calorie malnutrition: effect of deficient diets on enzyme levels of jejunal mucosa of rats $\mathrm{Br} J$ Nutr 21:5568

31. Nsi-Emvo E, Raul F 1984 Stimulation of lactase synthesis induced by starvation in the jejunum of adult rat. Enzyme 31:45-49

32. Scott 1, Batt RM, Maddison YE, Peters J 1981 Differential effect of glucocorticoids on structure and function of adult rat jejunum. Am $J$ Physiol 241:G306-G312

\title{
Age-Related Changes in the Adrenergic Control of Glycogenolysis in Rat Liver: The Significance of Changes in Receptor Density
}

\author{
JOHN L. BENDECK AND AKIHIKO NOGUCHI \\ Pediatric Research Institute, Cardinal Glennon Children's Hospital, Department of Pediatrics, St. Louis \\ University, Saint Louis, Missouri 63104
}

\begin{abstract}
The present study examined the developmental changes in the adrenergic control of glycogenolysis in the rat model. A relatively new $\beta$-adrenergic radioligand, ${ }^{125}$ I-iodocyanopindolol (ICP), was examined in binding assays with rat liver plasma membrane (LPM). ICP demonstrated both a higher specificity and a greater affinity for $\beta$-adrenergic receptors than any previously available $\beta$ adrenergic radioligand used to study rat LPM. Utilizing this new ligand it was found that $\beta$-adrenergic receptor density decreased from $114 \pm 4 \mathrm{fmol} \mathrm{mg}^{-1}$ in newborn LPM to $19 \pm 3 \mathrm{fmol} \mathrm{mg}^{-1}$ in adult male LPM. In contrast $\alpha$-adrenergic receptor density examined using ${ }^{3} \mathrm{H}$-prazosin increased from $161 \pm 14 \mathrm{fmol} \mathrm{mg}^{-1}$ in the newborn to 554 $\pm 59 \mathrm{fmol} \mathrm{mg}^{-1}$ in the adult male. The results of ICP displacement assays employing various $\beta$-adrenergic agonsists and antagonists indicated that ICP binding sites were $\beta_{2}$-adrenergic receptors. Both guanosine triphosphate and its nonhydrolyzable synthetic analog guanylyl-imidodiphosphate lowered the affinity of epinephrine for ICP binding sites similarly in newborn and adult LPM. Thus the coupling of receptor to guanine nucleotide regulatory protein appeared to be the same in both age groups examined. In isolated hepatocytes glycogen phosphorylase activation was mediated by $\beta_{2}$-adrenergic stimuli in the newborn and predominantly $\alpha$-adrenergic stimuli in the adult male. These results suggest that the change in glycogen phosphorylase activation from $\beta$ - to predominantly $\alpha$-adrenergic mechanisms seen with maturation is related to changes in receptor density. (Pediatr Res 19:862-868, 1985
\end{abstract}

Received October 29, 1984; accepted April 3, 1985.

Reprint requests John L. Bendeck, M.D., Cardinal Glennon Children's Hospital, 1465 South Grand Boulevard, St. Louis, MO 63104

\author{
Abbreviations \\ cAMP, $3^{\prime}: 5^{\prime}$-cyclic adenosine monophosphate \\ G'TP, guanosine triphosphate \\ $\operatorname{Gpp}(\mathrm{NH}) \mathrm{p}$, guanylyl-imidodiphosphate \\ ICP, ${ }^{125}$ I-iodocyanopindolol \\ LPM, liver plasma membrane \\ $\mathrm{Kd}$, dissociation constant
}

The mechanism of action of epinephrine on liver glycogenolysis varies depending on a number of factors. In certain species such as the guinea pig and rabbit epinephrine-induced glycogenolysis is mediated by the $\beta$-adrenergic receptor system $(1,2)$ while in the adult male rat the $\alpha$-adrenergic system predominates (3, 4 ). In the adult female rat glycogenolysis has recently been shown to be under the influence of both $\alpha$-and $\beta$-adrenergic stimuli (4). Several recent studies have also emphasized the importance of the age of the experimental animals on the adrenergic control of glycogenolysis. In these investigations it was demonstrated that $\beta$-adrenergic stimuli resulted in a marked rise in cAMP levels in hepatocytes from juvenile rats but little rise was noted in the hepatocytes from adult male rats. They also showed that glucose release from the cells occurred following both $\alpha$-and $\beta$-adrenergic stimuli in the juvenile hepatocytes but only following $\alpha$-adrenergic stimulation in the adult hepatocytes $(5,6)$. In another study using cultured fetal hepatocytes cAMP accumulation and glycogenolysis were mediated solely by $\beta$-adrenergic stimuli ( 7 ). However, the results of this study must be questioned since it has recently been reported that the culturing of adult male hepatocytes results in an increase in $\beta$-adrenergic receptor density and a changeover in adrenergic mediated glycogenolysis from $\alpha$ to $\beta$ control (8). Nonetheless, several of the latter studies seem 